\title{
Impacts of Ports along the Pilbara Coast, Western Australia - A Coastline of Global Geoheritage Significance that Services a Mineral-Rich Hinterland
}

\author{
MARGARET BROCX \\ Department of Environmental and Conservation Science, Murdoch University, Australia \\ geoheritage@iinet.net.au \\ VIC SEMENIUK \\ V \& C Semeniuk Research Group, Australia \\ vcsrg@iinet.net.au
}

\begin{abstract}
The Pilbara region in remote north-western A ustralia is mineral-rich with ores being mined/quarried and exported since the 1960s for the wealth of the A ustralian Nation and exported from a range of ports developed specifically for such purposes. However, the Pilbara Coast is one of few arid coasts around the World and the most arid coast in Australia - it stands unique as the most geomorphologically / geologically diverse arid coast globally and therefore has global coastal geoheritage significance. Ports along the Coast have been and continue to be developed without, or with little regard to their natural values, with impacts in terms of geoheritage and biological values - the parameters for port selection are based on engineering and economic perspectives of coastal proximity and coastal bathymetry in spite of information available for proper management and wise use of this coastal zone. Consequently, some significant coasts have been destroyed or markedly modified. With the intended growth of the mineral industry, there can be expected further destruction unless government agencies address the geoconservation issues but, in this context, there seems to be both a widespread lack of understanding on the part of government agencies of the geoheritage values of this Coast and a lack of geoethics. This contribution describes the natural heritage significance of the Pilbara Coast, the ports therein, their impacts and, from a geoethics viewpoint, the notion of centralizing ports rather than to indiscriminately construct facilities dictated by economic and port ownership. The Pilbara Coast provides a case study of geoethics where natural history assets of global significance conflict with industrial use.
\end{abstract}

\section{INTRODUCTION}

$\mathrm{T}$ he Pilbara Coast in the north-western Australia (Fig. 1) is globally unique and significant in its geoheritage values, coastal processes and landforms, stratigraphy, mangrove ecology, and biodiversity. It is one of eight tropical arid coasts in the World but markedly different to the rest; also, compared to the other coasts it is the most geologically, geomorphologically, and sedimentologically diverse of the arid coasts (Semeniuk, 1996) and thus globally significant (Brocx, 2008; Brocx and Semeniuk, 2015) and, in its natural state, should have been recognized as a World Heritage Site. The Pilbara Coast is also the most arid coast in Australia and, with coastal features present nowhere else in Australia, e.g., limestone barriers, arid-zone deltas, archipelago/ ria shores, extensive salt flats (Semeniuk, 1996; Semeniuk, 2012; Brocx and Semeniuk, 2015), it is nationally significant.

Comprised of Quaternary and Tertiary sediments, and Precambrian rock, the Pilbara Coast 


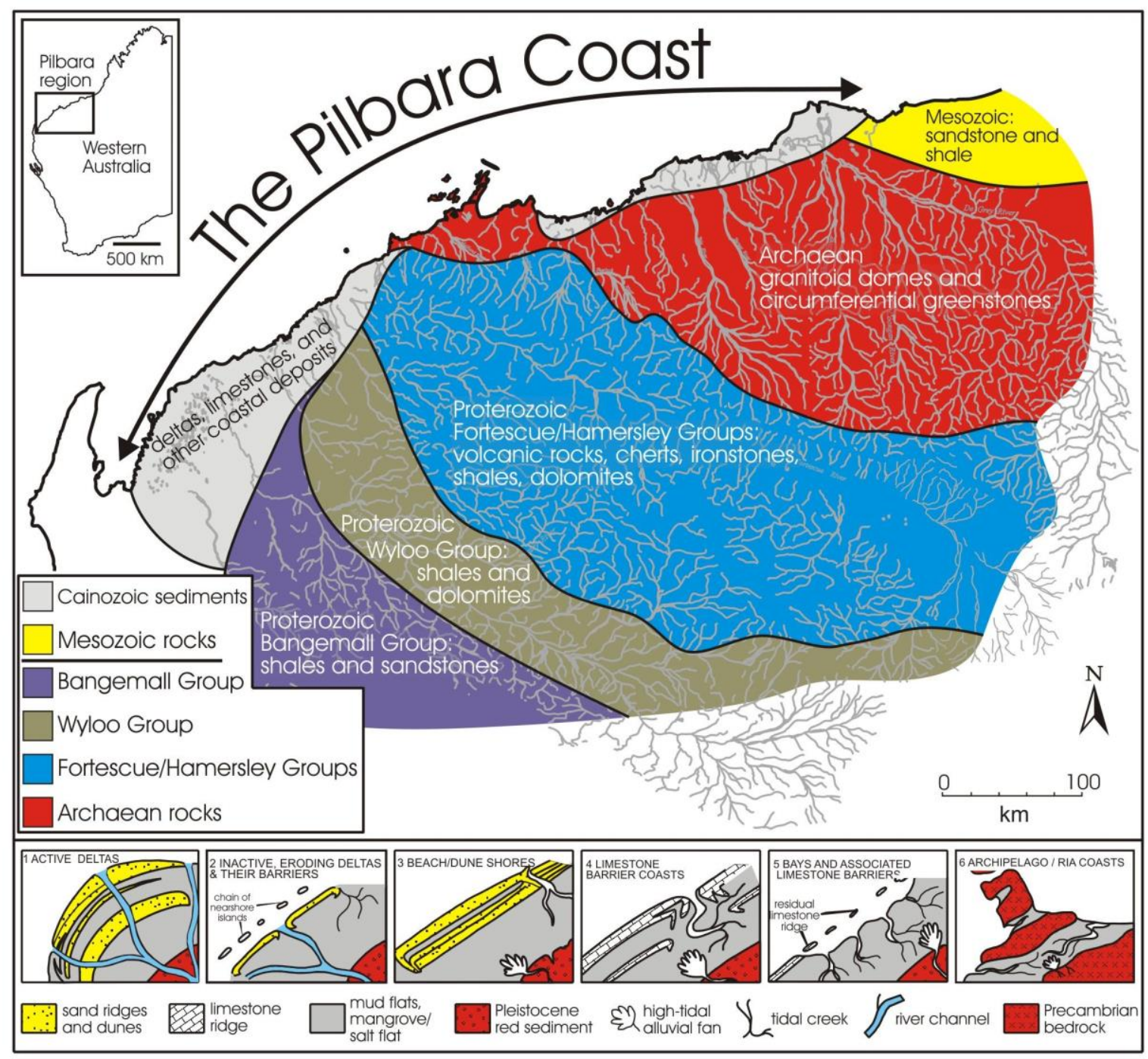

Figure 1: The Pilbara Coast in A ustralia, showing simplified geology, the river-dominated grain of the upland terrain, and, in the lower row of insets, the main coastal types in the region (modified after Semeniuk, 1996 and Brocx, 2008).

borders the Pilbara uplands, with a range of rivers draining the uplands to the coast. Quaternary coastal processes have produced different coastal types that represent stages of development of active to inactive arid-zone deltas, stages of Pleistocene limestone barrier island development and erosion, construction of Holocene dune barriers, and local outcrop of Precambrian rock (Semeniuk, 1996; and Fig. 1). The Pilbara Coast contains many features of geoheritage significance, from the large scale to the small scale (Semeniuk, 1996; Brocx, 2008): landforms such as deltas, Pleistocene oolitic limestone barriers and their mud-filled swales, archipelago/ ria shores, deltas that merge into linear dune fields, rocky shore erosion of Pleistocene limestones, Quaternary stratigraphy such as Pleistocene oolitic shoaling limestone sequences and limestone rocky shores, Holocene mangrove sequences, tempestites in beach/dune sands, and the complexities of beach-rock development. In the Precambrian rock sequences there is coastal geomorphology and micro-geomorphology reflective of the variable Precambrian rock types, and wellexposed Precambrian outcrops with lithology 
and structure emphasized by cliff erosion. Prior to the intensified mineral exploration, development of mines, solar salt production, natural gas extraction and liquefaction, and the export of these commodities during the past five decades (Brocx, 2008; Brocx and Semeniuk, 2015), the Pilbara region hosted pastoral and agricu 1tural activity which had impacts mainly on the hinterland (not the coast), and exports deriving from these latter industries took place from local jetties with relatively minimal effects on the coast regionally. How ever, since 1960 when the Australian Government lifted its restrictions on the export of iron ore, environmentally the Pilbara Coast has been slowly degrading, with mineral, solar salt, and natural gas development and export that has resulted in massive and multiple expansion of ports and in industrialization. This coast provides a case study of geoethics where natural history assets of global significance conflict with ind ustrial use.

The Pilbara region and its coast are remote (thousands of kilometers from major cities/ towns of Australia), and inhabited overwhelmingly with mine workers, laborers, machinery drivers and mechanics, and educated but industry-oriented personnel (geologists, mining engineers, and civil engineers), all largely with an ethos to create wealth personally and for the Nation. There exists little environmental/ conservation ethos, or a philosophy that can be used to focus on the geoethics of environment-damaging activities. A similar critical analysis of the Australian ethos and way-of-life was provided over 50 years ago by Horne (1964) in a book "The Lucky Country". This book was misinterpreted by most Australians, who never read past the title, as complimentary - in fact it was stinging criticism of the factors mentioned above - and so nothing has changed.

In our individual experience of 50 years each in environmental matters in Western Australia, we have concluded that several factors contribute to impede scrutiny of the environmental damage and poor management of regions such as the Pilbara Coast (some of these matters are discussed in Brocx [2008] and Brocx and Semeniuk [2015]). Firstly, the Pilbara Coast is remote; it contrasts with Perth, the capital of Western Australia. that has 2 million people, five universities, environmental issues that are proximal, and innumerable environmentallyoriented community groups (e.g., Friends of Yellagonga - http:/ / www.friend sofyellagonga. com.au/, The Conservation Council of Western Australia - http:/ / www.ccwa.org.au/, the Urban Bushland Council - http:// www.bush landperth.org.au/, and the Wetlands Conservation Society - http:/ / www.bush land perth.org.au/ member-groups/ 6-statewide -regional/ 78-wetland s-conservation-society, amongst many others). The environmental conflicts between conservation groups and developers and government agencies (such as Main Roads Western Australia, the Environmental Protection Authority, and the Department of Planning, amongst others) associated with development of bushland, wetlands, and the coast provide examples where there is focused conservation-oriented activity by the community because of informed groups and a critical mass of personnel. In the Pilbara Coast region, a coastal development is completed generally without social conflict because the area is largely unknown, there has been a relaxing of regulatory environmental safeguards (in spite of the fact there has been an increase in knowledge in environmental matters and geoheritage), and there is not the critical mass of interested and passionate people - the ease with which a port was developed at Cape Preston and the facilities at Port Hedland were expanded are examples.

Secondly, the ethos of the State government is driven by an economic imperative, and the mineral and fossil-fuel wealth has traditionally been the source of national wealth. According to government statistics, the mineral and energy industry in 2016-2017 in Western Australia was valued at $\$ 105$ billion (Department of Mines, Industry Regulation and Safety, 2017). Iron ore remained the State's highest value commodity with $\$ 67$ billion in sales with export of some 790 million tonnes of ore, and the total production from the energy sector was valued at $\$ 19$ billion. This shows the significance of the mining and energy industries to the government and to the economy of Western Australia.

Thirdly, while scientific literature on the region ideally should have or could have been used to 
raise the environmental consciousness of the scientific community, engineering community, regulatory authorities, or the public, it is either economically-oriented (e.g., geological and exploration-oriented literature), or "blue sky" research (e.g., Semeniuk, 1996), the latter either of little apparent use to the broader scientific and engineering community and lay-person, or has not been interpreted to be of use for environmental management or to aid the regulatory authorities to make informed decisions. That is, scientific literature on the region useful for conservation and ecologically-sound development is generally not read or understood by professional scientists and administrators. Academic staff in Australian universities traditionally used to be social and environmental watchdogs of Society but in this past half century and more specifically in this past quarter century this role has diminished. The significant influence of Industry funding to universities (with attendant consequences of curriculum control in industry-based and careeroriented courses) is one underlying reason for this. Also, government agency officers in management positions to manage/ safeguard the Pilbara Coast, in our experience and from our interviews (Brocx, 2008), are ill-read as to the global context of the Western Australian coast and do not keep up with the published work, do not understand it, or do not know how to use it for rational development - for instance, regulatory authority officers will focus on productivity of mangroves but will miss the holistic picture that the Pilbara Coast represents. Taking this a step further - generally having never ventured outside of Western Australia in a research capacity (travelling usually is for tourism), in our experience spanning decades, many regulatory authority officers are not even aw are of the uniqueness of the Pilbara Coast. As Brocx (2008) noted, none of the various Government agencies for conservation and environment in Western Australia, though needing to deal with holistic matters in environmental management, have had a qualified geologist or geoheritage practitioner on staff this situation still exists in 2017. Thus, published studies that ought to have resulted in global recognition of the Pilbara Coast in terms of geoheritage, or resulted in proper coastal management have not provided the anticipated positive environmental outcomes.

The matter of the effects of mining economically, sociologically, politically and, to some extent, environmentally in Western Australia has been discussed and debated by a number of authors (e.g., Harman and Head, 1982; Jacobs, 1995). Recently, Brueckner et al. (2014) provided a collection of articles on the impacts of contemporary resource exploitation in Western Australia as a basis for comparatively assessing their benefits and outcomes. And while there is discussion and debate on the social, economic, and political outcomes of resource development there has been relatively less focus on environmental considerations - this is within a context that Western Australia is viewed as a 'quarry' for minerals globally, and hence a major income earner. As such, environmental concerns generally have lower priority. Moreover, the environmental focus in debates is on biod iversity not geoheritage. The (geo)ethics of such economically-driven exploitation against an ethos of the International 'Declaration of the Rights of the Memory of the Earth' as form ulated by Martini (1993) has been discussed by Brocx (2008), Albrecht and Ellis (2014), and Brocx and Semeniuk (2015) with a suggestion that there be an alternative ethos to the current economically-driven, landscape-degrading, and geoheritage-destroying paradigm. One alternative to resource exploitation has been the suggestion for using the mineral-rich regions in Western Australia for their geological values as a focus for geotourism (Pforr et al., 2014). We argue that while geotourism provides an alternative base for the economy and, concomitantly, can raise the consciousness of the public to the importance of Geology and Geoheritage, there also are intrinsic values of Geology that are worthy of geoconservation in their own right without any connotations for economic benefit (e.g., the globally-significant Archaean zircon crystals of Jack Hills, Western Australia, or the globally-unique multi-dimensional geological features of Shark Bay, Western Australia; cf. Brocx and Semeniuk, 2007 and 2010). 


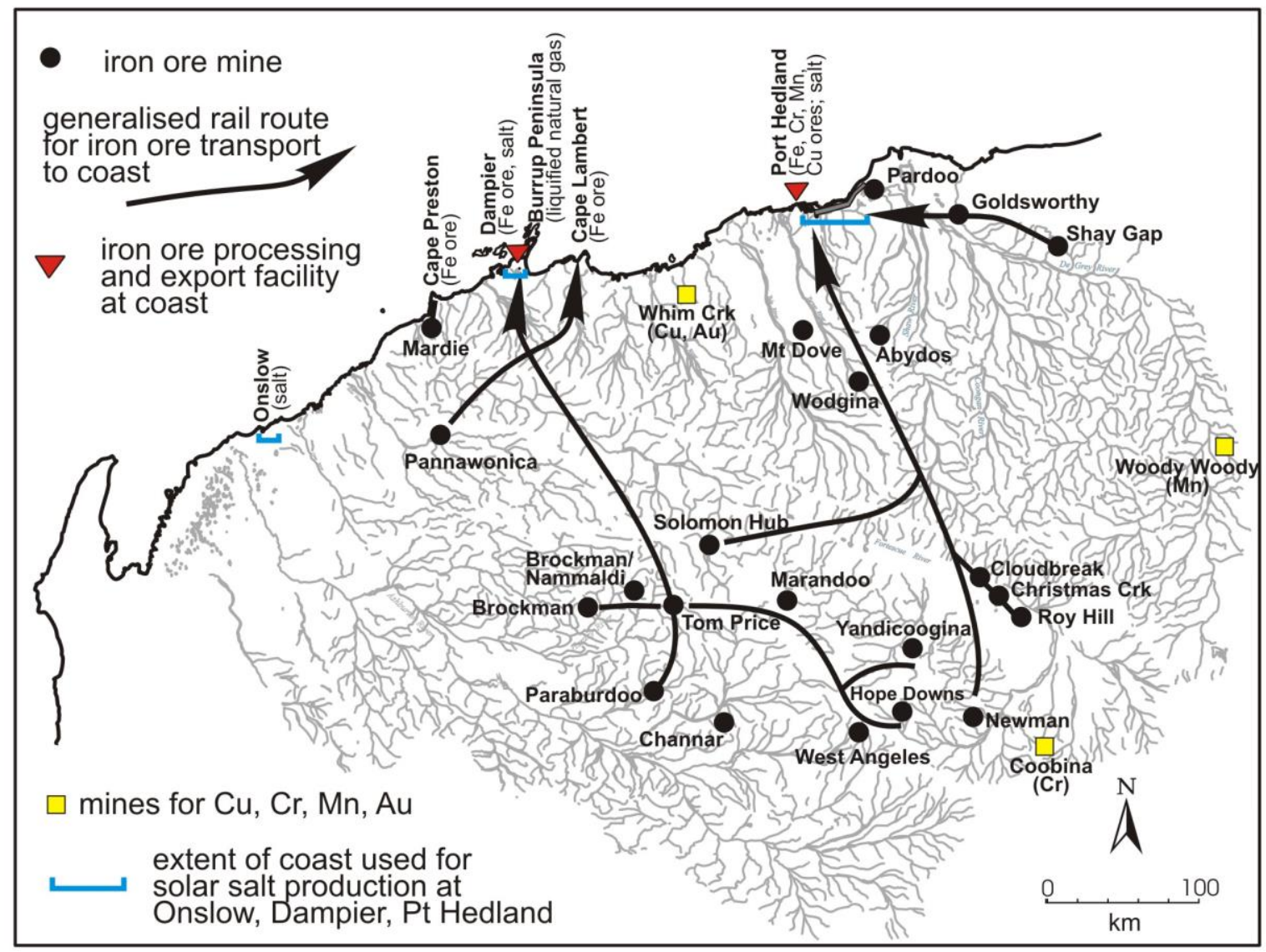

Figure 2: Main locations of iron ore mines (some locations represent amalgamations of a series of relatively closedspaced nearby sites) and the generalized pathways by which ore is delivered to the coast; also shown are locations of the ports and their export commodities. Location of the main sites for mining of $\mathrm{Cu}, \mathrm{Mn}$, and $\mathrm{Cr}$, and the location of solar salt operations also are shown. The main ports are: Onslow, Cape Preston, Dampier, Burrup Peninsula, Cape Lambert, and Port Hedland. Details of solar salt operations are presented in Brocx and Semeniuk (2015).

Indigenous peoples have been in the coastal Pilbara for tens of thousands of years, but their impact has been minimal (e.g., shell middens attesting to life styles and diet, and rock art celebrating their life with nature). In contrast, the arrival of European colonists and industrialists marked the beginning of major environmental impacts. And education seems to have made little difference to appreciating geoheritage and biological aspects of the Pilbara Coast: most geologists, ecologists in industrial employment, and the range of engineers seem not to have been touched by the uniqueness and beauty of the Pilbara Coast and have become party to the industrial exploitation and destruction of this special coastal environment. In terms of archaeology, ports and industrial developments in the coastal region also have major impacts on indigenous heritage. They particularly have had impact on internationally significant ancient rock engravings (petroglyphs) and archaeological sites (habitation, artefacts, middens) (Harrison, 2009; McDonald and Veth, 2009; Mulvaney, 2015). For instance, the petroglyphs on Burrup Peninsula (in the Dampier region; for location see Fig. 2) are considered to be one of the most significant archaeological sites in the world (Donaldson, 2011; Mulvaney, 2011; Black et al., 2017), however, the proximity of coastal industry either contributed to their degradation (Black et al., 2017) or to their direct destruction (Brocx, 2008). These matters of the impact of ports and industry on coastal indigenous heritage, though very important, are outside the scope of this paper. 
Given the background information above, this contribution examines ports along the Pilbara Coast, showing that they are placed with little regard to surrounding natural values, with consequent impacts on this Coast in terms of geoheritage and biological values in a lack of application of geoethics in best practices management. As Peppoloni and Di Capua (2015a) point out, geoscientists and geo-engineers should carry social and ethical responsibilities tow ard s society and the planet, particularly (in our view) in the conservation of geological heritage and geodiversity - the case of the industrialization of the Pilbara Coast transgresses this ethos. This paper describes: the mineralrich Pilbara hinterland and need for ports for exporting ores/ minerals; the types of locations for ports - parameters for selection; and impacts of ports and loss of geoheritage values.

\section{THE MINERAL-RICH PILBARA HINTERLAND AND THE NEED FOR PORTS}

The Pilbara hinterland is mineral-rich. It consists of several geological provinces (Hickman, 1983; Geological Survey of Western Australia, 1990):

1. Archaean Pilbara Craton (granitoids and fold ed greenstones);

2. Proterozoic sequences of volcanic rocks, ironstones, cherts, and shale; and

3. Proterozoic sequences of shale, dolomites, and cherts. Iron minerals, as hematite, goethite, and magnetite comprise the dominant ores in the Pilbara region occurring as layered ironstones in the Archaean and Proterozoic sequences, or a mesa-capping Tertiary goethite.

They occur at a range of localities in the region (Fig. 2). In addition, the Pilbara hinterland has been mined for ores of copper, chromium, and manganese and, locally, gold, lead, zinc, and silver (Geological Survey of Western Australia, 1990).

\section{LOCATIONS FOR PORT DEVELOPMENT, AND PARAMETERS FOR SELECTION}

To export ores from Western Australia, ports have been established and selected on engi- neering and economic bases of coastal proximity and bathymetry in spite of other information available to guide management and wise use of coastal zones. The main ports along the Pilbara Coast are: Onslow, Cape Preston, Dampier, Burrup Peninsula, Cape Lambert, and Port Hedland. The oldest port is Dampier exporting Fe ore since 1963. In terms of size and age, Port Hedland is the largest and the second oldest port in the Pilbara region, commencing exporting Fe ores in 1966, originally from Shay Gap and Mount Newman; today it handles ores of $\mathrm{Fe}, \mathrm{Cr}, \mathrm{Mn}$, and $\mathrm{Cu}$, and solar salt. Cape Lambert commenced exporting Fe ore in 1972. The various ports servicing the oil/ gas indu stry on the Burrup Peninsula were established in the 1980s. The most recent port construction was at Cape Preston in 2010. While Port Hedland, Dampier, and Cape Lambert have been exporting ores since the 1960 s, more recently, Fe ore has been mined at Mardie and Roy Hill, and other locations extended from and near older mine sites (e.g., Marandoo, Brockman, Channar) (Fig. 2), and newly exploited Fe ores have been exported from recently developed facilities (e.g., Cape Preston) or from existing expanded older ports. Ports require:

1. some proximity to a mine site;

2. existing sheltered inlet, or opportunity to build loading jetties;

3. natural deep entrance channel (steep shores and steep near-shore bathymetry are ideal), or one that can be readily dredged; Precambrian rock archipelagos are best;

4. stable terrain landward of the jetty or port for infrastructures/ facilities (regularlyflooded delta plains would not qualify, mobile dunes might not qualify, but Precambrian rock ridges are ideal).

Thus, some terrains along the Coast have not been selected as ports. Ideal terrain for port construction is Precambrian rock (e.g., Dampier, Cape Lambert, Cape Preston) or Pleistocene limestone (e.g., Port Hedland). Once a site is selected for a port, the coast and immediate hinterland may require modification to maximize its use for port facilities. With these modifications arrive the problems of altering geomorphic and geological features and possible 


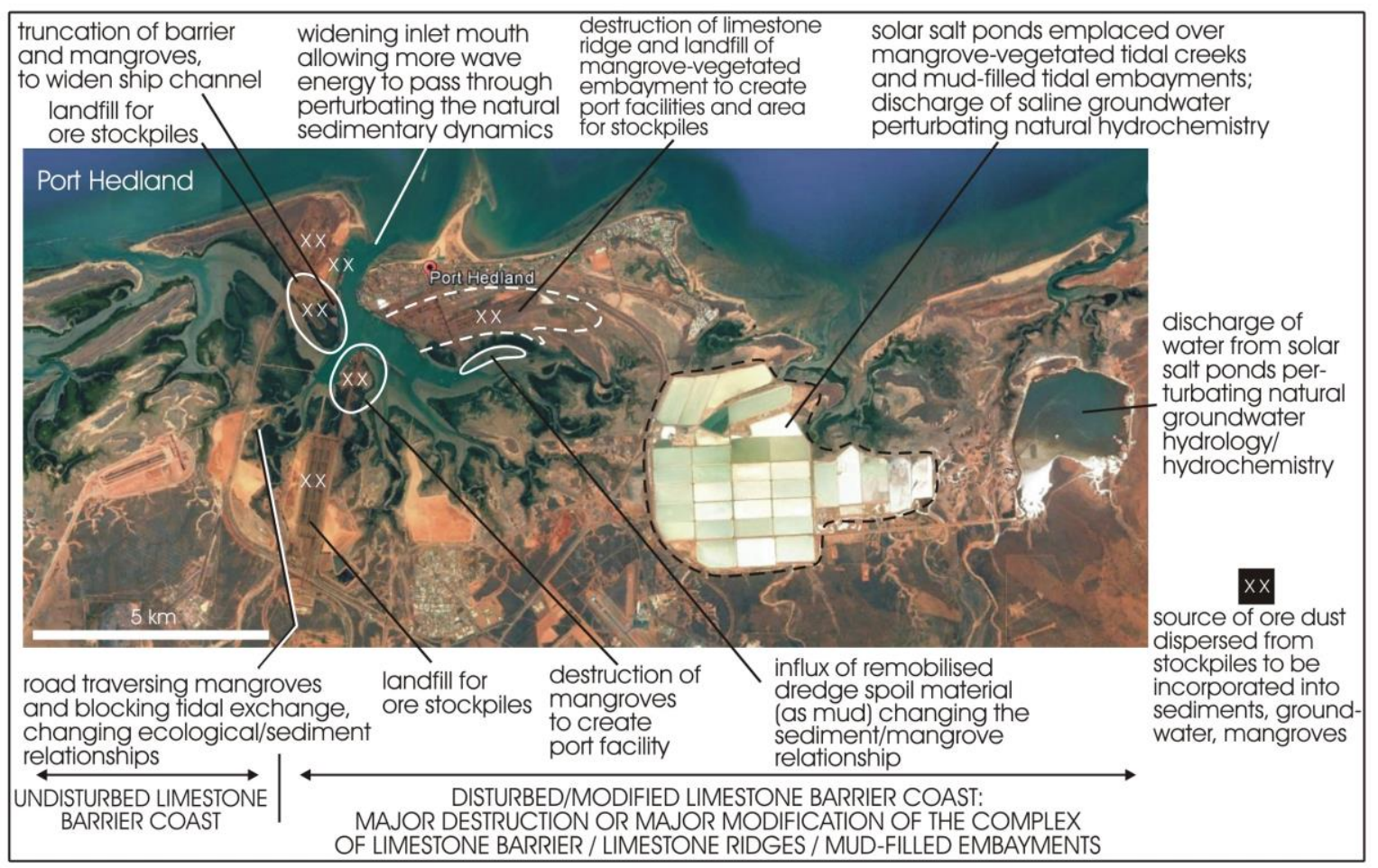

Figure 3: Annotated aerial photograph showing range of industrial impacts in the Port Hedland area, a limestone barrier coastal setting.

destruction of features of geoheritage significance. Where a port has been developed, there are two patterns to its history. If it is Stateoperated (such as Port Hedland), there can be further port expansion as additional inland mining interests may utilize existing ports. The State-operated ports then expand to become multi-tasking, exporting whatever commodity is brought to the coast. If the port is vested in a mining company, there is no sharing or leasing of facilities and each company establishes its own port of dispatch.

\section{IMPACTS OF EXISTING PORTS AND LOSS OF GEOHERITAGE VALUES}

The impacts of the existing ports on terrain and the loss of geoheritage values are manifold and range from the large scale (where there is levelling of terrain at the coast, removal of gravel from coastal alluvial fans, and quarrying of coastal dune sand) to the small scale (with destruction of innumerable unique and special geological features, diagenetic features, and arid-zone-specific micro-geomorphic features). The larger scale impacts of the various ports and industries on the geoheritage values of the Pilbara Coast are listed below and described in more detail by V \& C Semeniuk Research Group (1996) and Brocx and Semeniuk (2015), the latter discussing the geoethical implications of loss of geoheritage values associated with solar salt production. In the context that the Pilbara Coast is globally unique, loss of these sites/ features of geoheritage significance is of some consequence (assessed using Brocx and Semeniuk, 2007):

- Onslow: barrier dune modification;

- Cape Preston: destruction of the most southerly expression of archipelago/ ria shores and a specific range of rock types at the coast; this was an internationally significant site;

- Dampier and Burrup Peninsula: major modification of archipelago/ ria shores and islands; this was a internationally significant site and is the central location of three such shores along the Coast; 
- Cape Lambert: major modification of archipelago/ ria shores and dune coast; this was an internationally significant site and the northern location of only three such shores along the Pilbara Coast;

- Port Hedland: major modification of (Pleistocene) limestone barrier ridges and loss of geomorphology of tidal-creek-dissected inter-ridge mud-filled swales, and tidal flats (Fig. 3); to create the port, large mud-filled swales were excavated or in-filled to form foundations for infrastructures, and the inlet channel was dredged for ship access; at smaller scales, much Quaternary history and stratigraphy was lost; this was an internationally significant site and a main location of limestone barriers along the Coast.

More details on the impact of industry specifically on the mangrove component of the coast are presented in Semeniuk and Cresswell (2018).

While there are a range of export commodities and industrial activities associated with ports, an example of the impacts of a port on the coast is provided by the activities and infrastructures for Fe ore processing, refining, and export (V \& C Semeniuk Research Group, 1996) but the same principles can be described for solar salt production and other export commodities. In the Pilbara region, $\mathrm{Fe}$ ore is mined in inland quarries, crushed, and transported to the coast by rail for further processing (secondary and tertiary crushing) and shipping; mines and ports of dispatch are shown in Figure 2. Iron ore industries in coastal areas have a limited range of infrastructures and activities associated with them and they are relatively contained systems; from mine to port they are:

- rail lines rail yards, car dumpers to receive ore from rail systems;

- crushers;

- conveyors;

- pelletizing plants and sinter plants;

- rescreening plants;

- fuel and oil storage tanks, power generation stations;

- vehicles, vehicle storage sheds, vehicle and machinery workshops, equipment storage sheds;
- water storage tanks;

- pipe networks for w ater and fuel;

- $\operatorname{roads}$

- administration facilities, amenities buildings, accommodation areas;

- ore stockpiles;

- lagoons/ ponds (for cooling water, slug catchers, etc.);

- jetties.

These infrastructures have impacted on the coast, though not all are developed at the one coastal site (V \& C Semeniuk Research Group, 1996).

The Fe ore industries established on the Pilbara Coast have required extensive modification of coastal land, with the type and degree of modification dependent on the setting. All such coastal sites have involved rail and road construction, coast alteration and dredging for ports, jetties and harbors, and dredge spoil disposal. Facilities sited on bedrock archipelago/ ria coasts, and areas of rugged terrain involved terrain modification and landfill to level (flatten) the sites for stockpiles and infrastructure. Those facilities on limestone barriers required construction of causeways for rail and roads (crossing high tidal flats), and tidal land modification (landfill through dredge spoil disposal) to create sites for infrastructures. Barrier islands are not large enough to support infrastructures and so adjoining tidal lands were reclaimed.

\section{DISCUSSION AND CONCLUSIONS}

The Pilbara Coast is special, in comparison to other coasts in Australia and Globally (Semeniuk, 1996), with distinctive coastal forms, geochemical products and stratigraphy, all of which reflect a Quaternary history of complex sedimentation, aridity, and cyclonic storms. As a result, the Coast is distinguished by a range of features: construction of arid-zone deltas, delta destruction and sediment redistribution, cyclone-induced erosion and sedimentation, mangrove ecology and associated deposits, evolution of coastal ground water hypersalinity, and formation of beachrock, high-tidal crusts and gypsum precipitates, amongst others. The Pilbara Coast thus provides a globally important model, unparalleled elsewhere in the 
world, for the development of a range of megascale landforms through to smaller-scale geomorphic, sedimentary, stratigraphic, and diagenetic products developed within an arid climate, providing for the Earth Sciences an important and unique model of arid zone coastal sedimentation, diagenesis, and stratigraphic evolution (Semeniuk, 1996).

Loss of geoheritage values and geodiversity along the Pilbara Coast denies humanity the opportunity to learn of the globally important great stories of coastal history and geological products that this region has to offer or (where already destroyed) had to offer. This is a factor that Bohle (2015) highlights by emphasizing the importance of "selling" Earth sciences through storylines to raise the consciousness of the public in regards to the importance of the geosciences in daily life, but we add the importance of the geosciences to understanding Earth history, Earth diversity, and ultimately biodiversity.

Some of the industrial impacts along the Pilbara Coast took place during the 1960s to 1980s in ignorance of the significance of this coast but recent ports at Onslow and Cape Preston were constructed after the principles and concepts of geoheritage and biological conservation were established. Moreover, there are industrial activities presently being planned or expanded with current knowledge that the Pilbara Coast is a globally unique. For example, planning for coastal industries in the Pilbara Region is based on a report by Dover Consultants (1995) which advocates a special emphasis on "maximizing the natural advantages of Western Australia" by promoting new coastal heavy industry associated with deep water ports including further development at Dampier, Karratha and Port Hedland. In addition, the Department of Resources Development and the Department of Minerals and Energy, actively promote development of the Pilbara through its Pilbara Development Commission, based on the Pilbara 21 report (Pilbara 21 Study Group, 1992), as well as on studies such as the Basic Raw Materials Survey Karratha (Martinick, 1997), and the activities of Geological Survey of Western Australia (Rudduck, 1999). These government bodies have development and economic grow th as an over-riding paradigm, leaving environmental matters to the Environmental Protection Au- thority (EPA). However, if the EPA recommends against a given development on environmental grounds, the historical trend has been to drive development by Ministerial decisions and use of the State Agreements Act. Each State Agreement is negotiated ad hoc to be then ratified as an Act of Parliament to en able the project to proceed outside most State laws, affording privileges and environmental concessions to facilitate development (Hillman, 2006).

Development has changed irreversibly the character and potential of the Pilbara (Kerr, 1979) with loss of many geoheritage sites and a cultural dislocation as a result of unplanned exploitation of mineral resources in an environmentally unique region. This outcome is the product of over forty years of ad hoc planning decisions and resource exploitation for shortterm economic benefit of the development partners, i.e., the State Government and the developers, contradicting Kerr's optimistic prediction of the social and economic benefits that development would bring. Clearly, with the special nature of the Pilbara Coast in terms of its rich geoheritage and the type of economically-driven developments already undertaken, there is a need for strategic planning and policy development that can balance the conflicting aspects of geoheritage, indigenous culture, and the pursuit of wealth by exploiting raw materials. To date, little has been carried out in this regard in terms of policy.

This case study of port development along the Pilbara Coast highlights the conflicting and invariably competing values present in the use of natural coastal geoheritage. Substantial tracts of the coast of this ancient land scape have been and continue to be overprinted by resource development based on government policies that have not been publicly debated. Decisions have been and continue to be made ad hoc, and are founded on capitalist values. Due to indifference and ignorance, or both, of the natural values of the Pilbara Coast, these decisions have resulted in a loss or modification of tribal lands, loss of ancient rock art sites, and loss of areas rich in geoheritage values.

The Pilbara is mineral rich and as it is further exploited for minerals, it may be expected to see more ports. A fundamental philosophy that 
would be environment-friendly would be State-wide planning that limits the number of ports in the region, i.e., rather than having a multiplicity of ports, commensurate with every mining company that is floated, there needs to be planning such that there is a centralized approach.

Another important aspect to discuss is that Western Man, in Western Australia, sees the natural environment as a resource to exploit or utilise. Rather than the Pilbara Coast being seen as a unique coastal "wilderness", it is viewed as "a Place for Man and Nature", with clearing of vegetation, levelling of rocky terrain for building sites, installing transportable building, digging trenches for pipes, bringing in plastic chairs, etc., which emphasizes the idea that "Man is part of Nature" regardless that Man brings in unnatural and artificial structures and components. This we reject, and view that the Pilbara Coast is a globally distinct environment much of which is wild and natural and should be left as a wilderness.

The problems highlighted for the Pilbara Coast are similar to the problems and geoethics involved that are currently being faced in eastern Australia, e.g., developing ports for economic/ employment opportunities in the region of the Great Barrier Reef World Heritage area (UNESCO, 2014). But such problems extend beyond Australia - they are prevalent throughout the World and need addressing in principle to find "a way-out-of-the-conundrum". Suggestions to help resolve such problems include: bringing Geoheritage into the consciousness of conservation managers so that it is addressed in development proposals and plans; creating an inventory of coastal features and identifying their significance (using the Geoheritage Toolkit of Brocx and Semeniuk, 2009); and coastal zones identified as of high significance should be treated as high geoconservation zones (the extent that Man intrudes, or manages, or has multiple use of the other coastal zones of lesser significance should be treated in a graded response). Geoethics, with an objective to protect the Earth and features of geology, as a new emerging endeavor (as discussed by Peppoloni and Di Capua, 2015b), needs to be addressed by regulatory and coastal managing agencies.

\section{REFERENCES}

Albrecht G. and Ellis N. (2014). The Ethics of Resource Extraction and Processing: Two Western Australian Case Studies. In: Brueckner M., Durey A., Mayes R. and Pforr C. (eds), Resource Curse or Cure? - On the Sustainability of Development in Western Australia. Springer-Verlag Berlin. pp 43-57.

Black J.L., MacLeod I.D. and Smith B.W. (2017). Theoretical effects of industrial emissions on colour change at rock art sites on Burrup Peninsula, Western Australia. Journal of Archaeological Science: Reports, 12: 457-462, http:/ / dx.doi.org/ 10.1016/ j.jasrep.2017.02.026.

Bohle M. (2015). Simple geoethics: an essay on daily Earth science. In: Peppoloni S. and Di Capua G. (eds), Geoethics: the Role and Responsibility of Geoscientists, The Lyell Collection, The Geological Society Special Issue, 419, http:/ / doi.org/ 10.1144/ SP419.3.

Brocx M. (2008). Geoheritage: from global perspectives to local principles for conservation and planning. Western Australian Museum (Monograph). 175p. ISBN 978-1-920843-35-9.

Brocx M. and Semeniuk V. (2007). Geoheritage and geoconservation - history, definition, scope and scale. Journal of the Royal Society of Western Australia, 90: 53-87.

Brocx M. and Semeniuk V. (2009). Developing a tool-kit for geoheritage and geoconservation in Western Australia. ProGeo New s, (1): 5-9.

Brocx M. and Semeniuk V. (2010). The geoheritage significance of crystals. Geology Today, 26: 216-225.

Brocx M. and Semeniuk V. (2015). The solar salt ponds along the Pilbara Coast, Western Australia - a case study of a coastline of global geoheritage significance used for industrial purposes. In: Wyss M. and Peppoloni S. (eds), Geoethics: the Role and Responsibility of Geoscientists. The Lyell Collection, The Geological Society Special Issue, 419, http:/ / dx.doi.org/ 10.1144/ SP419.18.

Brueckner M., Durey A., Mayes R. and Pforr C. (eds) (2014). Resource Curse or Cure? - On the Sustainability of Development in Western Australia, Springer-Verlag Berlin.

Department of Mines, Industry Regulation and Safety (2017). Mineral and petroleum - statistics digest 2016-2017. Government of Western Australia, Perth, Western Australia. 
Donaldson M. (2011). Understanding the rocks: rock art and the geology of Murujuga (Bu rrup Peninsula). The Journal of the Australian Rock Art Research Association, 28: 35-43.

Dover Consultants (1995). A background paper for a State heavy industry policy: a submission to Government. Report to Department of Resources Development, Perth, Western Australia.

Geological Survey of Western Australia (1990). The geology of Western Australia. Geological Survey of Western Australia Memoir 3.

Harman E.J. and Head B.W. (eds) (1982). State, capital and resources in the north and west of Australia. University of Western Australia Press, Nedlands, Western Australia.

Harrison R. (2009). The archaeology of the Port Hedland coastal plain and implications for understanding the prehistory of shell mounds and middens in northwestern Australia. Archaeology in Oceania, 44: 81-98.

Hickman A.T. (1983). Geology of the Pilbara Block and its environs: Western Australia Geological Survey, Bulletin 127.

Hillman R. (2006). The future role for State Agreements in Western Australia, http:/ / www .austlii.edu.au/ au/ journals/ A URELaw Jl/ 2006/ 58.pdf (accessed 28 February 2018).

Jacobs M. (1995). Sustainability and community: environment, economic rationalism and the sense of place. Australian Planner, 32(2):109-115.

Horne D. (1964). The Lucky Country. Penguin Books, Australia.

Kerr A. (1979). Mining developments in Australia's North West. In: Gentilli J. (ed), Western Land scapes. University of Western Au stralia Press, Perth.

Martini G. (ed) (1993). Actes du premier symposium international sur la protection au patrimonie geologique. [Proceedings of the First Symposium on Earth Heritage Conservation, Digne, France, 11.16 June 1991]. Memoires de la Societé géologique de France, NS p 165, 276.

Martinick W.G. (1997). Basic raw material survey, Karratha. Report by Martinick and Associates P/L to Department of Resources Development, Perth.

McDonald J.O. and Veth P. (2009). Dampier Archipelago petroglyphs: archaeology, sci- entific values and National Heritage Listing. Archaeology in Oceania, 44: 49-69.

Mulvaney K. (2011). About time: towards a sequencing of the Dampier Archipelago petroglyphs of the Pilbara region, Western Australia. Records of the Western Australian Museum Supplement, 79, Part 1, pp. 30-49, 10.18195/ issn.0313-122x.79.2011.030-049.

Mulvaney K. (2015). Murujuga Marni. University of Western Australian Press, Crawley, Western Australia.

Peppoloni S. and Di Capua G. (2015a). Introduction. In: Peppoloni S. and Di Capua G. (eds), Geoethics: the Role and Responsibility of Geoscientists. The Lyell Collection, The Geological Society Special Issue, 419: 14, https:/ / doi.org/ 10.1144/ SP419.21.

Peppoloni S. and Di Capua G. (2015b). Chapter 1: The Meaning of Geoethics. In: Wyss M. and Peppoloni S. (eds), Geoethics: Ethical Challenges and Case Studies in Earth Sciences. Elsevier, Amsterdam, ISBN 978-0-12799935-7, pp 3-14.

Pforr C., Dowling R. and Newsome D. (2014). Geotourism: A Sustainable Development Alternative for Remote Locations in Western Australia? In: Brueckner M., Durey A., Mayes R. and Pforr C. (eds), Resource Curse or Cure? - On the Sustainability of Development in Western Australia. Springer-Verlag Berlin, pp 152-162.

Pilbara 21 Study Group (1992). Final strategy report / Pilbara 21. Perth, 83 p.

Rudduck I. (1999). Mineral occurrences and exploration: potential of the West Pilbara. Geological Survey of Western Australia, Perth.

Semeniuk V. (1996). Coastal forms and Quaternary processes along the arid Pilbara coast of Northwestern Australia. Palaeogeography Palaeoclimatology Palaeoecology, 123: 49-84.

Semeniuk V. (2012). Predicted response of coastal wetlands to climate changes - a Western Australian model. Hydrobiologia, Vol. 708, Issue 1, p. 23-43, doi: 10.1007/ s10750-012-1159-0.

Semeniuk V. and Cresswell I.D. (2018). Australian mangroves - anthropogenic impacts by industry, agriculture, ports, and urbanisation. In: Finkl C.W. and Makow ski C. (eds), Threats to Mangrove Forests: Hazards, Vulnerability, and Management, Dordrecht, The Netherlands: Springer (in press). 
UNESCO (2014). Great Barrier Reef state of conservation, http:/ / whc.unesco.org/ en/ news/ 1099 (accessed 28 February 2018).

V \& C Semeniuk Research Group (1996). Coastal types, mangroves, and industrial impacts along the arid Pilbara Coast, Volumes 1-12, 1994-1996. Report to Department of Resources Development, Perth. Copy housed in the Battye Library in Perth by The Wetlands Research Association. 